\title{
Kepatuhan Pengiraan Zakat Pendapatan Kumpulan Profesional di Universiti Pendidikan Sultan Idris
}

\author{
Fidlizan Muhammad*, Azila Abdul Razak, Fatimah Salwa Abdul Hadi, Nor Hamizah Saidin
}

Jabatan Ekonomi, Fakulti Pengurusan dan Ekonomi, Universiti Pendidikan Sultan Idris, 35900 Tanjong Malim, Perak, Malaysia

*Corresponding author: fidlizan@fpe.upsi.edu.my

\begin{abstract}
Sources of income of an individual from the current runemeration are various and different according to working sectors and designations.. Apart from the income known as the basic salary, an employee also benefits from other forms of income such as allowances, bonuses, incentives and others by monthly or annually. For the profesional group, side income is also earned through consultation or expertise activities, supervisory, research and others. Due to the expanding of income sources, the compliance in calculating the total payable zakat is significant. In relation to that, every eligible Muslim must accomplish the payment of income zakat to ensure the gained and earned wealth is free from the rights of others. Therefore, this study aims to identify the compliance level of zakat income from the aspect of income calculation from each earned source of income. This study employs the descriptive analysis from ten income sources earned by academic staffs involving 112 Muslim academicians who are currently attached to Universiti Pendidikan Sultan Idris, Perak as the respondents. Outcome of the analysis indicates that the level of knowledge about the source of income to be calculated in zakat is high for basic salary and monthly fixed allowances while moderate and low levels are detected for other sources. This level of knowledge is found to be the reason for the inability to calculate the actual income in the income zakat calculation among respondents. The implication of this study proves to the need among the authorities to give more explanation on income zakat to ensure that the wealth ownership of an individual is purer as well as to improve the justice in wealth distribution.
\end{abstract}

Keywords: Compliance, calculate, income zakat, source of income, descriptive.

\begin{abstract}
Abstrak
Sumber pendapatan seseorang individu daripada penggajian semasa adalah pelbagai dan berbeza mengikut sektor pekerjaan dan jawatan. Selain pendapatan dikenali gaji pokok, seseorang pekerja turut menikmati pendapatan berbentuk elaun, bonus, insentif dan sebagainya sama ada secara bulanan atau tahunan. Bagi kumpulan profesional pula, pendapatan sampingan turut diperoleh menerusi aktiviti perundingan atau kepakaran, penyeliaan, penyelidikan dan sebagainya. Memandangkan sumber pendapatan ini semakin meluas, kepatuhan dalam menghitung jumlah pendapatan yang perlu ditunaikan zakat adalah signifikan. Sehubungan itu, setiap individu Muslim berkelayakan perlu menunaikan zakat pendapatan bagi memastikan harta yang dicari dan diperoleh adalah bersih daripada hak orang lain di dalamnya. Justeru itu, kajian ini bertujuan mengenal pasti tahap kepatuhan zakat pendapatan yang dilihat dari aspek pengiraan jumlah pendapatan daripada setiap sumber penggajian yang diperoleh. Kajian ini menggunakan analisis deskriptif daripada 10 sumber pendapatan diperoleh oleh kakitangan akademik melibatkan 112 orang kakitangan akademik Muslim yang berkhidmat di Universiti Pendidikan Sultan Idris, Perak sebagai responden kajian. Hasil analisis menunjukkan tahap pengetahuan mengenai sumber penggajian yang perlu dihitung dalam pengiraan zakat adalah tinggi bagi gaji pokok dan elaun tetap bulanan dan tahap sederhana dan rendah bagi sumber-sumber lain. Tahap pengetahuan ini didapati merupakan punca kepada ketidakupayaan responden untuk menghitung pendapatan sebenar dalam pengiraan zakat pendapatan. Implikasi kajian ini menunjukkan keperluan kepada pihak berautoriti untuk memberikan lebih penerangan berkaitan zakat pendapatan bagi memastikan pemilikan harta individu lebih bersih serta meningkatkan keadilan dalam agihan kekayaan.
\end{abstract}

Kata Kunci: Kepatuhan, hitung, zakat pendapatan, sumber pendapatan, deskriptif

(C) 2016 Penerbit UTM Press. All rights reserved

\subsection{PENGENALAN}

Zakat pendapatan merupakan sumber pungutan zakat paling tinggi diperoleh oleh institusi zakat di Malaysia. Sumber ini menyumbang antara antara 40 hingga 60 peratus daripada keseluruhan kutipan zakat tahunan. Kutipan zakat ini menunjukkan trend meningkat dari setahun ke setahun. Antara tahun 2012 ke tahun 2013, kutipan zakat pendapatan di beberapa negeri contohnya di Pusat Pungutan Zakat (PPZ) Wilayah Persekutuan Kuala Lumpur menunjukkan pertambahan sebanyak 20 peratus (PPZ, 2014), Lembaga Zakat Selangor (LZS) sebanyak 18.5 peratus (LZS, 2014) serta 16 peratus di Pusat Zakat Negeri Sembilan (Laman Web PZNS). Pertambahan dalam kutipan ini dipengaruhi oleh dua sebab. Pertama ialah pewartaan kewajipan zakat pendapatan pada peringkat kebangsaan dan negeri di Malaysia telah menimbulkan kesedaran masyarakat Muslim di Malaysia untuk menunaikan kewajipan rukun Islam ini (Norlela \& Hairunnizam 2014). Kedua ialah kefahaman yang semakin meluas dalam kalangan masyarakat melalui pendidikan dan juga promosi berterusan oleh pihak bertanggungjawab. Faktor ini didapati signifikan mempengaruhi masyarakat untuk menunaikan zakat berdasarkan pendapatan yang diperoleh (Hairunnizam, Sanep \& Mohd Ali, 2007; Nur Barizah \& Hafiz Majdi, 2010). Walaupun peningkatan kutipan ini memberi gambaran yang positif terhadap kepatuhan pembayaran zakat, namun sejauh mana ketepatan pembayar membuat pengiraan jumlah 
pendapatan yang sewajarnya dilaksanakan zakat perlu dikaji secara terperinci. Hal ini disandarkan kepada tiga justifikasi utama. Pertama, zakat pendapatan merupakan zakat dalam kategori kontemporari atau hasil ijtihad para ulama. Zakat ini dikenali sebagai zakat mal almustafad yang merangkumi pendapatan daripada penggajian dan juga sumber profesional. Bagi kumpulan pekerjaan profesional khususnya, tahap pekerjaan yang disandang melayakkan untuk memperoleh pelbagai sumber profesional sama ada dalam organisasi atau di luar organisasi. Kedua, maklumat pada kalkulator zakat secara atas talian adalah terhad. Item pendapatan yang jelas didapati terhad kepada pendapatan penggajian iaitu gaji, elaun dan bonus, manakala sumber pendapatan lain yang menerangkan pendapatan profesinal agak samar. Maklumat terhad berkaitan sumber profesional ini berkemungkinan menyebabkan wujudnya ketinggalan menghitung jumlah pendapatan sebenar yang wajib ditunaikan zakat pendapatan. Ketiga, pengetahuan atau pendidikan merupakan faktor penting terhadap kepatuhan atau kesedaran masyarakat untuk membayar zakat pendapatan sebagaimana dibuktikan dalam kajian Hairunnizam et al. (2007), Nur Barizah dan Hafiz Majdi (2010) serta Nur Azura, NorAzlina dan Nor Fadzlin (2005). Namun demikian, sejauh mana elemen atau konsep literasi berkaitan zakat pendapatan difahami oleh masyarakat Islam belum mendapat kajian yang menyeluruh. Atas justifikasi ini, kajian ini cuba untuk meneliti kepatuhan pengiraan zakat pendapatan melibatkan sumber-sumber pendapatan yang diperoleh oleh kumpulan profesional di Universiti Pendidikan Sultan Idris, Perak. Implikasi kajian ini dapat mengisi lompang jurang maklumat berkaitan kajian zakat pendapatan dan seterusnya dapat digunakan oleh pihak bertanggungjawab bagi melaksanakan strategi pendidikan atau promosi yang lebih berkesan bagi mencapai matlamat rukun Islam ini secara syumul. Untuk perbincangan, kajian ini disusun dalam lima bahagian. Bahagian kedua membincangkan berkaitan kajian-kajian lepas yang berkaitan zakat pendapatan, metodologi dan dapatan analisis dalam bahagian ketiga dan keempat, manakala kesimpulan dan implikasi kajian pada bahagian kelima.

\subsection{KAJIAN LEPAS}

Tanggungjawab menunaikan zakat adalah bersifat individu dan tersirat. Ia melibatkan kesedaran dan keikhlasan seseorang individu dalam menunaikan hak harta menuruti perintah yang diwajibkan oleh Allah S.W.T. Atas faktor ini, Aidit (1988) mengkategorikan manusia ini kepada tujuh kumpulan antara ialah membayar disebabkan wujudnya undang-undang zakat yang mewajibkan untuk membayar, lebih mengutamakan bayaran cukai berbanding zakat, tidak membayar disebabkan kejahilan, bayaran zakat dianggap beban, mengelak dari membayar jumlah sewajarnya serta beranggapan zakat fitrah sahaja wajib ditunaikan. Memandangkan kategori ini adalah banyak, Mujaini (1995) merumuskan kategori ini kepada tiga kelompok iaitu golongan yang berpendapat zakat pendapatan merupakan zakat yang digalak untuk ditunaikan atas faktor ketiadaan dalil, golongan yang berpandangan sebagai hukum wajib atas faktor maslahah dan golongan yang berpandangan wajib atas dalil al-Quran dan al-Sunnah. Rentetan wujudnya kelompok dan pandangan yang pelbagai ini, maka kajian berkaitan kepatuhan membayar zakat pendapatan banyak dilaksanakan oleh pengkaji. Kajian-kajian ini dapat diperingkatkan kepada dua tahap. Pengkaji pada peringkat awal seperti Abidin (1982), Mohd Ali (1989), Mahmood Zuhdi (1992), Mujaini Tarimin (1995) dan Zawavri (2002) mengkaji dari sudut teoritikal dan falsafah berkaitan kewajaran zakat pendapatan dilaksana. Hal ini disebabkan zakat pendapatan merupakan antara jenis zakat yang diikhtilaf atau tidak disepakati kewajipannya. Namun demikian, Muzakarah Jawatankuasa Fatwa Majlis Kebangsaan di Malaysia telah menetapkan bahawa zakat pendapatan adalah wajib ditunaikan melalui pewartaan fatwa pada tahun 1997.

Setelah daripada itu, munculnya kajian-kajian berbentuk empirikal yang menganalisis pelbagai aspek berkaitan zakat pendapatan dan kebanyakkan berfokus kepada elemen kepatuhan dan kesedaran dalam kalangan pembayar zakat. Hairunnizam, Sanep dan Mohd Ali (2007) mengkaji faktor-faktor yang signifikan mempengaruhi kesedaran masyarakat untuk membayar zakat menggunakan analisis logistik. Antara faktor yang penting ditemui dalam hasil kajian mereka ialah umur, taraf perkahwinan, pendapatan dan juga mekanisme pembayaran zakat. Kajian oleh Mohd Ali, Hairunnizam dan Nor Ghani (2004) pula menunjukkan peratusan pembayaran zakat adalah kecil dalam kakitangan profesional. Antara faktor yang dikenal pasti ialah pengetahuan dan kurangnya penguatkuasaan. Nur Barizah dan Hafiz Majdi (2010) melibatkan kakitangan profesional di UIAM serta Nur Azura, NorAzlina dan Nor Fadzlin (2005) di UUM turut berkongsi faktor yang sama. Dalam menangani isu ini, Kamil $(2003,2006)$ menyatakan keperluan untuk melaksanakan penguatkuasaan yang lebih tegas bertujuan meningkatkan komitmen individu berkelayakan untuk mengetahui tanggungjawab dan menunaikan zakat. Faktor kecekapan institusi dalam membuat kutipan dan agihan turut didapati signifikan untuk menarik keyakinan pembayaran zakat melalui institusi formal (Hairunnizam, 2004; Sanep, 2004).

Konsep penswastaan zakat walaupun berupaya untuk meningkatkan kutipan, namun isu ketidakpuasan masyarakat terhadap keefisienan agihan dan pengurusan masih berlanjutan (Nor Ghani, Mariani, Jaafar \& Nahid, 2001). Analisis keefisienan menggunakan data input dan output melibatkan jumlah kakitangan, jumlah perbelanjaan operasi, jumlah kutipan dan agihan daripada analisis pengumpulan data (DEA) oleh Nor Azlina dan Abdul Rahim (2012) masih mendapati ketidakcekapan ini berlaku. Turut menemui hasil rumusan kajian yang sama dalam mengukur kecekapan antara institusi zakat yang diuruskan oleh pihak negeri dan swasta ialah Hairunnizam, Sanep dan Radeah (2009). Sehubungan itu, bagi meningkatkan kecekapan dalam institusi zakat adalah disaran untuk mengoptimumkan penggunaan sumber, kaedah pengurusan dan operasi serta sumber bagi memastikan kutipan dan agihan yang disasarkan oleh institusi dapat dicapai dan diterima secara positif oleh masyarakat. Individu yang menguasai kemahiran syariah dan profesional melibatkan pekerja dan majikan perlu diutamakan bagi mencapai kecekapan ini (Sadeq, 1995). Selain daripada zakat pendapatan, isu ketidakpatuhan pembayaran zakat kepada institusi formal turut dianalisis menggunakan data zakat fitrah di Malaysia secara am (Fidlizan et al. 2015) dan negeri khususnya seperti Selangor, Perak (Mohd Yahya et al. 2013) dan Terengganu (Siti Saufirah, Hairunnizam \& Sanep 2015). Kesemua dapatan ini turut mencadangkan keperluan penguatkuasaan yang lebih sistematik dilakukan bagi memastikan objektif zakat dapat dicapai dengan sempurna.

Walaupun terdapat lompang yang boleh ditambah baik oleh pihak institusi zakat, namun kajian yang menumpukan kepada mengenal pasti elemen pendidikan yang perlu didedahkan kepada masyarakat untuk lebih celik berkaitan zakat masih belum mendapat kajian mendalam. Pengaruh pengetahuan terhadap kepatuhan telah banyak dibuktikan dalam kajian percukaian khususnya. Antaranya ialah Hungerford dan Yolk (1990), Roberts (1994), Eriksen dan Fallan (1996), Fallan (1999), Richardson (2006), Anis Barieyah dan Ling (2009) Mohd Rizal, Mohd Rusyidi dan Wan Fadillah (2013) serta Rini (2014). Rumusan utama daripada kajian-kajian ini menunjukkan kepentingan pengetahuan dalam percukaian yang dibuktikan berupaya untuk meningkat atau memperbaiki sikap dan gelagat kepatuhan dalam kalangan masyarakat. Memandangkan cukai dan zakat mempunyai persamaan dari aspek perlu dibayar bagi tujuan agihan tertentu, maka aspek pengetahuan atau literasi zakat khususnya berkaitan punca-punca pendapatan yang perlu diambil kira dalam menghitung 
pendapatan perlu diteliti bagi meningkatkan tahap kesedaran dan komitmen masyarakat untuk lebih teliti dalam aspek pemilikan harta. Rentetan itu, hasil kajian ini dapat memberi maklumat dalam menambahbaik polisi serta strategi terhadap agensi berkaitan zakat untuk memastikan objektif rukun Islam ini dapat direaliasikan.

\subsection{METODOLOGI}

Untuk mencapai objektif, kajian berbentuk tinjauan melalui borang soal selidik dilaksana. Borang ini terbahagi kepada tiga bahagian. Perincian berkaitan soal selidik adalah seperti Jadual 1. Borang soal selidik yang merangkumi pernyataan, skala dan jenis analisis yang sesuai serta selari dengan objektif kajian telah dirujuk kepada tiga pakar yang terdiri daripada seorang ahli akademik yang bertugas di Universiti Utara Malaysia, dan dua wakil industri yang terdiri daripada seorang pegawai di Pusat Pungutan Zakat Kuala Lumpur dan seorang pegawai eskekutif di Majlis Agama Islam Negeri Perak. Rentetan itu, bagi mendapatkan data kajian, borang soal selidik ini telah diedarkan kepada semua kakitangan akademik di Universiti Pendidikan Sultan Idris (UPSI), Perak menggunakan edaran secara atas talian dalam tempoh masa 3 bulan bermula pada bulan Februari hingga April 2015. Berdasarkan statistik, bilangan kakitangan akademik di UPSI sehingga tahun 2014 ialah 580 orang yang terdiri daripada 314 orang lelaki dan 206 orang perempuan di mana 90 peratus kakitangan adalah beragama Islam. Dalam tempoh pungutan data dilaksana, sebanyak 120 borang soal selidik dikembalikan dengan 112 borang diisi dengan lengkap. Jumlah borang soal selidik yang dianalisis mewakili antara 20 hingga 22 peratus bilangan kakitangan akademik Muslim di UPSI.

Kaedah analisis deskriptif kekerapan dan peratus digunakan pada untuk menganalisis data borang soal selidik bahagian A dan B, manakala analisis silang bagi mengenal pasti elemen kepatuhan responden menghitung jumlah pendapatan yang perlu ditunaikan zakat pendapata pula dalam bahagian $\mathrm{C}$.

Jadual 1 Ringkasan borang soal selidik

\begin{tabular}{lcll}
\hline Bahagian & Bilangan item & Penerangan & Skala Ukuran \\
\hline A (Maklumat Asas Responden) & 6 & $\begin{array}{l}\text { Jantina, umur, perkahwinan, bilangan tanggungan, } \\
\text { kelayakan akademik, kaedah bayaran zakat }\end{array}$
\end{tabular}

B (i- Pengetahuan Konsep Zakat)

B (ii- Pengetahuan item Zakat Pendapatan)

C (Kepatuhan Pengiraan Jumlah Pendapatan)
10

$10^{\mathrm{a}}$

$10^{\mathrm{a}}$
Hukum zakat, konsep haul dan nisab, kadar zakat, konsep agihan dan asnaf, pengurusan zakat, pengiraan zakat, cukai pendapatan, rebat cukai.
Tahu, tidak tahu,

Tahu, tidak tahu, tidak pasti

Gaji pokok, elaun, elaun pentadbiran, elaun kenderaan, tunggakan gaji, bonus/imbuhan, program eksekutif, bayaran kepakaran, pemeriksa kertas, aktiviti penyelidikan dan pengkomersilan

Gaji pokok, elaun, elaun pentadbiran, elaun kenderaan, tunggakan gaji, bonus/imbuhan, program eksekutif, bayaran kepakaran, pemeriksa kertas, aktiviti penyelidikan dan pengkomersilan
Perolehan Sumber: Ya, Tidak

Kepatuhan Menghitung; Ya, tidak

\footnotetext{
a item pendapatan ini diteliti berdasarkan laman sesawang kalkulator pengiraan zakat atas talian yang disediakan oleh Pusat Zakat dan Majlis Agama Islam Negeri setiap negeri di
} Malaysia.

\subsection{HASIL ANALISIS}

Maklumat berkaitan responden dalam kajian ditunjukkan pada Jadual 2. Responden kakitangan akademik dalam kajian ini terdiri daripada 55 orang lelaki dan 57 orang wanita dengan majoriti responden memiliki kelayakan akademik peringkat sarjana dan Doktor Falsafah iaitu 85.7 peratus. Umur responden pula majoritinya adalah antara 33 hingga 43 tahun. Dari segi perkahwinan pula, majoritinya berkahwin dan mempunyai tanggungan seramai 1 hingga 3 orang (49.1\%), 4 hingga 6 orang (38.4\%) dan lebih daripada 7 orang $(0.9 \%)$. Dari segi amalan pembayaran zakat semasa, 85 orang $(75.9 \%)$ membayar zakat pendapatan melalui kaedah potongan gaji bulanan, 18 orang (16.1\%) melalui bayaran di kaunter, 4 orang (3.6\%) melalui atas talian dan 5 orang pula membayar terus kepada asnaf. 
Jadual 2 Maklumat responden

\begin{tabular}{|c|c|c|c|}
\hline & Keterangan & Kekerapan & Peratus (\%) \\
\hline \multirow{2}{*}{ Jantina } & Lelaki & 55 & 49.1 \\
\hline & Perempuan & 57 & 50.9 \\
\hline \multirow[t]{4}{*}{ Umur (tahun) } & 22 hingga 32 & 5 & 4.5 \\
\hline & 33 hingga 43 & 68 & 60.7 \\
\hline & 44 hingga 54 & 29 & 25.9 \\
\hline & 55 dan ke atas & 10 & 8.9 \\
\hline \multirow[t]{3}{*}{ Status Perkahwinan } & Belum Berkahwin & 7 & 6.3 \\
\hline & Berkahwin & 105 & 93.8 \\
\hline & Duda/Janda/Tunggal & - & - \\
\hline \multirow[t]{4}{*}{ Tanggungan } & Tiada & 13 & 11.6 \\
\hline & 1 hingga 3 & 55 & 49.1 \\
\hline & 4 hingga 6 & 43 & 38.4 \\
\hline & 7 dan lebih & 1 & 0.9 \\
\hline \multirow[t]{2}{*}{ Kelayakan Akademik } & Ijazah Pertama & 16 & 14.3 \\
\hline & Sarjana \& Doktor Falsafah & 96 & 85.7 \\
\hline Pendapatan & Potongan Gaji & 85 & 75.9 \\
\hline \multirow[t]{3}{*}{ Semasa } & Bayaran di Kaunter & 18 & 16.1 \\
\hline & Bayaran Atas Talian & 4 & 3.6 \\
\hline & Agihan Terus & 5 & 4.5 \\
\hline
\end{tabular}

Jadual 3 pula menunjukkan tahap pengetahuan responden berkaitan konsep zakat. Secara umum, pengetahuan responden berkaitan hukum zakat dan pihak bertanggungjawab memungut zakat adalah tinggi. Namun demikian, penelitian secara lebih terperinci menunjukkan terdapat sebilangan responden tidak mengetahui konsep haul (3.6\%), nisab (25\%), kadar zakat (11\%), agihan zakat (20\%), kalkulator atas talian (9.8\%), rebat cukai pendapatan (1.8\%) dan perbezaan bayaran cukai dan zakat $(25.9 \%)$.

Jadual 3 Pengetahuan konsep zakat

\begin{tabular}{|c|c|c|c|}
\hline \multirow[t]{2}{*}{ Bil } & \multirow[t]{2}{*}{ Pernyataan } & \multicolumn{2}{|c|}{ Keterangan } \\
\hline & & Tahu & Tidak Tahu \\
\hline 1. & Zakat wajib bagi orang Islam yang berkemampuan. & $\begin{array}{c}112 \\
(100)\end{array}$ & - \\
\hline 2. & Zakat wajib dibayar jika mencukupi haul (tempoh) dan nisab (timbangan). & $\begin{array}{l}112 \\
(100)\end{array}$ & - \\
\hline 3. & Haul (tempoh) pengiraan zakat adalah setahun. & $\begin{array}{l}108 \\
(96.4)\end{array}$ & $\begin{array}{c}4 \\
(3.6)\end{array}$ \\
\hline 4. & Nisab (timbangan) pengiraan zakat berdasarkan 85 gram emas. & $\begin{array}{c}84 \\
(75)\end{array}$ & $\begin{array}{l}28 \\
(25)\end{array}$ \\
\hline 5. & Kadar zakat yang diwajibkan ialah $2.5 \%$. & $\begin{array}{c}101 \\
(90.2)\end{array}$ & $\begin{array}{c}11 \\
(9.8)\end{array}$ \\
\hline 6. & Zakat diagih kepada lapan (8) asnaf. & $\begin{array}{c}92 \\
(82.1)\end{array}$ & $\begin{array}{c}20 \\
(17.9)\end{array}$ \\
\hline 7. & $\begin{array}{l}\text { Majlis Agama Islam Negeri dan Pusat Pungutan Zakat adalah badan } \\
\text { berautoriti memungut zakat di Malaysia. }\end{array}$ & $\begin{array}{c}112 \\
(100)\end{array}$ & - \\
\hline 8. & $\begin{array}{l}\text { Pengiraan zakat pendapatan boleh dibuat menggunakan kalkulator zakat } \\
\text { secara online. }\end{array}$ & $\begin{array}{c}101 \\
(90.2)\end{array}$ & $\begin{array}{c}11 \\
(9.8)\end{array}$ \\
\hline 9. & Bayaran zakat boleh ditolak daripada bayaran cukai pendapatan. & $\begin{array}{c}110 \\
(98.2)\end{array}$ & $\begin{array}{c}2 \\
(1.8)\end{array}$ \\
\hline 10. & Bayaran zakat murah berbanding cukai pendapatan. & $\begin{array}{c}83 \\
(74.1) \\
\end{array}$ & $\begin{array}{c}29 \\
(25.9) \\
\end{array}$ \\
\hline
\end{tabular}


Jadual 4 pula menunjukkan pengetahuan responden dalam kategori kumpulan profesional berkaitan item-item sumber pendapatan yang perlu dikira dalam menentukan jumlah pendapatan zakat bagi seseorang individu. Majoriti responden mengetahui bahawa gaji pokok adalah item utama dalam pengiraan jumlah pendapatan zakat. Item berikutnya yang menunjukkan tahap pengetahuan yang baik ialah elaun bulanan (elaun kakitangan/keraian, perumahan, bantuan sara hidup) seramai 90 orang (80.4), manaka tahap pengetahuan sederhana ialah bonus atau imbuhan seramai 67 orang (59.8\%) dan khidmat kepakaran seramai 58 orang (51.8\%). Bagi sumber-sumber pendapatan lain, tahap pengetahuan adalah rendah iaitu elaun pentadbiran (47.3\%), pemeriksa kertas (45.5\%), bayaran program eskekutif (43.8\%), tunggakan gaji (37.5\%), aktiviti penyelidikan/pengkomersilan (35.7\%) dan elaun kenderaan (23.2\%). Tahap pengetahuan yang berbezabeza ini menunjukkan bahawa wujud lompang makumat dalam kalangan kakitangan profesional untuk membuat pengiraan jumlah pendapatan zakat. Walaupun kumpulan ini telah melaksanakan zakat pendapatan, namun terdapat kemungkinan berlakunya keciciran individu untuk menentukan jumlah pendapatan zakat sebenar. Penerangan yang berterusan daripada pihak berwajib berkaitan zakat pendapatan amat penting untuk ditambah baik bagi memastikan setiap individu yang berkelayakan dapat menunaikan zakat ini secara lebih tepat. Antaranya ialah menambah baik kalkulator zakat atas talian supaya item-item pendapatan ini disediakan secara khusus sebagaimana item gaji, elaun dan bonus.

Jadual 4 Pengetahuan item zakat pendapatan

\begin{tabular}{|c|c|c|c|c|}
\hline Bil & Item Pendapatan & Tahu & Tidak Tahu & Tidak Pasti \\
\hline 1. & Gaji Pokok & $\begin{array}{c}108 \\
(96.4)\end{array}$ & $\begin{array}{c}4 \\
(3.6)\end{array}$ & - \\
\hline 2. & Elaun Bulanan & $\begin{array}{c}90 \\
(80.4)\end{array}$ & $\begin{array}{c}14 \\
(12.5)\end{array}$ & $\begin{array}{c}8 \\
(7.1)\end{array}$ \\
\hline 3. & Elaun Pentadbiran & $\begin{array}{c}53 \\
(47.3)\end{array}$ & $\begin{array}{c}25 \\
(22.3)\end{array}$ & $\begin{array}{c}34 \\
(30.4)\end{array}$ \\
\hline 4. & Elaun Kenderaan & $\begin{array}{c}26 \\
(23.2)\end{array}$ & $\begin{array}{c}24 \\
(21.4)\end{array}$ & $\begin{array}{c}62 \\
(55.4)\end{array}$ \\
\hline 5. & Tunggakan Gaji & $\begin{array}{c}42 \\
(37.5)\end{array}$ & $\begin{array}{c}16 \\
(14.3)\end{array}$ & $\begin{array}{c}54 \\
(48.2)\end{array}$ \\
\hline 6. & Bonus/Imbuhan/Anugerah & $\begin{array}{c}67 \\
(59.8)\end{array}$ & $\begin{array}{c}8 \\
(7.1)\end{array}$ & $\begin{array}{c}37 \\
(33)\end{array}$ \\
\hline 7. & Bayaran Program Eksekutif & $\begin{array}{c}49 \\
(43.8)\end{array}$ & $\begin{array}{c}21 \\
(18.8)\end{array}$ & $\begin{array}{c}42 \\
(37.5)\end{array}$ \\
\hline 8. & Khidmat Kepakaran & $\begin{array}{c}58 \\
(51.8)\end{array}$ & $\begin{array}{c}16 \\
(14.3)\end{array}$ & $\begin{array}{c}38 \\
(33.9)\end{array}$ \\
\hline 9. & Pemeriksa Kertas & $\begin{array}{c}51 \\
(45.5)\end{array}$ & $\begin{array}{c}11 \\
(9.8)\end{array}$ & $\begin{array}{c}50 \\
(44.6)\end{array}$ \\
\hline 10. & Aktiviti Penyelidikan & $\begin{array}{c}40 \\
(35.7)\end{array}$ & $\begin{array}{c}15 \\
(13.4)\end{array}$ & $\begin{array}{c}57 \\
(50.9)\end{array}$ \\
\hline
\end{tabular}

( ) peratus

Jadual 5 pula merupakan analisis kepatuhan menghitung jumlah pendapatan yang layak ditunaikan zakat mengikut sumbersumber pendapatan penggajian dan profesional yang diperoleh oleh responden. Dua sumber pendapatan bulanan secara tetap yang menunjukkan tahap kepatuhan yang tinggi ialah gaji pokok dan elaun bulanan. Bagi sumber pendapatan iaitu gaji pokok, 100 peratus responden menghitung elemen ini dalam pengiraan zakat, manakala elaun bulanan pula sebanyak $79 \%$, manakala 24 orang (21 \%) tidak menghitung item ini. Analisis kepatuhan bagi sumber pendapatan lain pula menunjukkan tahap yang rendah kecuali bonus atau imbuhan dengan 55 peratus responden memasukkan sumber ini dalam penjumlahan pendapatan zakat, manakala 45 peratus pula sebaliknya. Pendapatan penggajian yang diperoleh sebagai ganjaran tambahan sesuatu jawatan menunjukkan 26 orang penerima elaun kenderaan tidak menghitung elaun ini dalam jumlah pendapatan zakat dan elaun pentadbiran pula sebanyak 65 peratus. Jenis-jenis pendapatan profesional yang diterima oleh ahli akademik turut menunjukkan trend ketidakpatuhan yang sama. Responden yang menerima pendapatan daripada aktiviti pengajaran daripada program eksekutif didapati tidak menghitung pendapatan ini dalam pengiraan zakat. Ketidak patuhan menghitung pendapatan juga ditunjukkan daripada bayaran perkhidmatan kepakaran seramai 40 orang (68\%), pemeriksa kertas (78\%) dan aktiviti penyelidikan/pengkomersilan (79\%). Jika dilihat kepada statistik analisis ini, ia membuktikan bahawa literasi kumpulan profesional berkaitan zakat pendapatan profesional masih sederhana. Walaupun kewajipan rukun Islam dilaksana, namun tahap pematuhan bagi mencapai objektif zakat untuk membersihkan harta daripada milik individu lain belum dicapai sepenuhnya. Senario ini sewajarnya mendapat perhatian oleh semua pihak sama ada individu pembayar atau agensi kutipan untuk bertindak lebih progresif bagi memastikan hak pembangunan sosio ekonomi golongan asnaf dapat direalisasikan melalui rukun Islam ini. 
Jadual 5 Kepatuhan dalam menghitung zakat pendapatan

\begin{tabular}{|c|c|c|c|c|}
\hline \multirow[t]{2}{*}{ Bil. } & \multirow[t]{2}{*}{ Kategori } & \multirow[t]{2}{*}{ Bilangan } & \multicolumn{2}{|c|}{$\begin{array}{l}\text { Sumber dihitung dalam pengiraan } \\
\text { zakat }\end{array}$} \\
\hline & & & Ya & Tidak \\
\hline 1. & Gaji Pokok & 112 & $112(100)$ & $0(0)$ \\
\hline 2. & Elaun Bulanan & 112 & $88(79)$ & $24(21)$ \\
\hline 3. & Elaun Pentadbiran & 35 & $12(35)$ & $23(65)$ \\
\hline 4. & Elaun Kenderaan & 26 & 0 & $26(100)$ \\
\hline 5. & Tunggakan Gaji & 39 & $7(18)$ & $32(82)$ \\
\hline 6. & Bonus/Imbuhan/Anugerah & 107 & $58(55)$ & $49(45)$ \\
\hline 7. & Bayaran Program Eksekutif & 37 & 0 & $37(100)$ \\
\hline 8. & Khidmat Kepakaran & 62 & $20(33)$ & $40(68)$ \\
\hline 9. & Pemeriksa Kertas & 89 & $20(23)$ & $69(78)$ \\
\hline 10. & Aktiviti Penyelidikan & 112 & $24(22)$ & $88(79)$ \\
\hline
\end{tabular}

Berdasarkan hasil perbincangan, didapati kumpulan profesional mempunyai sumber pendapatan yang pelbagai. Walaupun kewajipan zakat telah dilaksana, namun hasil penelitian membuktikan bahawa masih wujud beberapa sumber pendapatan zakat yang tidak dihitung secara lengkap. Sehubungan itu, pendedahan berkaitan kewajipan individu untuk memahami konsep zakat pendapatan secara lebih jelas perlu dilaksana secara lebih agresif. Penemuan ini menunjukkan bahawa sebahagian besar masyarakat Islam masih memahami pendapatan yang wajib dizakat terhad kepada pendapatan tetap yang diperoleh gaji dan elaun bulanan sahaja.

\subsection{KESIMPULAN DAN CADANGAN}

Individu yang berkerja mendapat pelbagai bentuk pendapatan daripada pekerjaan yang dilaksana. Bagi kumpulan profesional, selain pendapatan daripada gaji pokok dan elaun, golongan ini layak untuk menerima pendapatan tambahan bersesuaian dengan bidang, jawatan dan kedudukannya. Pekerjaan sebagai ahli akademik di universiti contohnya tutut menerima pendapatan tambahan daripada aktiviti pengajaran, penyelidikan, perundingan dan sebagainya sama ada melibatkan agensi dalam organisasi dan luar organisasi. Namun demikian, sejauh mana golongan bekerjaya mengetahui sumber-sumber pendapatan yang diperoleh ini wajib ditunaikan haknya.

Berdasarkan hasil analisis, wujud lompang kefahaman yang memerlukan reformasi maklumat untuk dilaksana oleh pihak pengurusan zakat khususnya. Amalan menghitung zakat semasa menunjukkan bahawa sumber pendapatan terhad kepada gaji pokok, elaun dan bonus. Sebilangan kecil sahaja individu yang membuat pengiraan zakat daripada setiap punca pendapatan yang diperoleh. Senario ini menunjukkan bahawa tahap pengetahuan masyarakat dalam membuat pengiraan pendapatan zakat sebenar berada pada tahap yang sederhana. Rentetan itu, pihak pengurusan zakat disaran untuk memberikan penerangan yang lebih berinformasi berkaitan zakat pendapatan ini dari semasa ke semasa. Memandangkan pengiraan anggaran zakat boleh dilaksana secara individu melalui kalkulator zakat atas talian, maka penyediaan kalkulator yang informatif adalah amat signifikan untuk dilaksana. Item sumber pendapatan yang lebih terperinci dengan definisi ringkas dicadang bagi membolehkan pembayar zakat menghitung jumlah pendapatan yang tepat.

\section{Penghargaan}

Penyelidikan ini dibiayai oleh Pusat Pengurusan Penyelidikan dan Inovasi (RMIC-UPSI)

\section{Rujukan}

Aidit Ghazali. (1988). Zakat Satu Tinjauan. Selangor: IBS Buku Sdn Bhd.

Anis Barieyah Mat Bahari \& Lai Ming Ling. (2009). Introducing Tax Education in Non-Accounting Curriculum in Higher Education: Survey Evidence. Journal of Financial Reporting and Accounting, 7(1), 37-51.

Eriksen, K \& Fallan, L.(1996). Tax Knowledge and Attitudes Toward Taxation: A Report on a Quasi Experiment. Journal of Economic Psychology, 17(3), 387-402.

Fallan, L. (1999). Gender, Exposure to Tax Knowledge, and Attitudes Towards Taxation: An Experimental Approach. Journal of Business Ethics, 18(2), 173-184.

Fidlizan Muhammad, Mohd Yahya Mohd Hussin, Azila Abdul Razak \& Salwa Amirah Awang. (2015). Ketirisan Bayaran Zakat Fitrah Terhadap Institusi Formal di Malaysia. Sains Humanika, 5(1),27-32. 
Hairunnizam Wahid, Sanep Ahmad \& Mohd Ali Mohd Nor. (2007). Kesedaran Membayar Zakat Pendapatan di Malaysia. Islamiyyat, 29 , 53-70.

Hairunnizam Wahid, Sanep Ahmad \& Radiah Abdul Kader (2009). Pengagihan Zakat oleh Institusi Zakat di Malaysia: Mengapa Masyarakat Islam Tidak Berpuas Hati? Jurnal Syariah, 17(1),89-112.

Hungerford, H.R \& Yolk, T.L. (1990). Changing Learner Behavoir through Environmental Education. The Journal of Environmental Education, 21 (3), 8-21.

Kamil Md. Idris. (2006). Kesan Persepsi Undang-undang dan Penguatkuasaan Zakat Terhadap Gelagat Kepatuhan Zakat Pendapatan Gaji, dalam Abdul Ghafar Ismail dan Hailani Muji Tahir (eds.) Zakat: Pensyariatan, Perekonomian dan Perundangan. Bangi: Penerbit UKM.

Kamil Md. Idris.(2003). Kesan Persepsi Undang-undang dan Penguatkuasan Zakat Terhadap Gelagat Kepatuhan Zakat Pendapatan Gaji. Kertas Kerja dibentangkan di Muzakarah Pakar Zakat, Universiti Kebangsaan Malaysia.

Kamil Md. Idris.(2003). Kesan Persepsi Undang-undang dan Penguatkuasan Zakat Terhadap Gelagat Kepatuhan Zakat Pendapatan Gaji. Kertas Kerja dibentangkan di Muzakarah Pakar Zakat, Universiti Kebangsaan Malaysia.

Lembaga Zakat Selangor. (2014). Laporan Pengurusan Zakat Selangor 2013. Selangor: Majlis Agama Islam Selangor (MAIS).

Mahmood Zuhdi Abdul Majid. (1993). Zakat Gaji dan Pendapatan Profesional. Jurnal Syariah, 1(1), 32-33.

Mahmood Zuhdi Abdul Majid. (2002). Peranan Zakat dalam Pembangunan Ummah, dalam Nik Mustapha Nik Hassan(ed.), Ekonomi Islam dan Pelaksanaannya di Malaysia. Kuala Lumpur: Institut Kefahaman Islam Malaysia

Mohd Ali Bahrum. (1989). Zakat ditinjau dari Perspektif Sosial, Undang-undang dan Taksiran. Kuala Lumpur: Dewan Pustaka Islam.

Mod. Nor. (2004). Kesedaran Membayar Zakat Pendapatan di Kalangan Kakitangan Profesional Universiti Kebangsaan Malaysia. Islamiyyat, 26 (2), 59-68.

Mohd Rizal Palil, Mohd Rusyidi Md Akir \& Wan Fadillah Wan Ahmad. (2013). The Perception of Tax Payers on Tax Knowledge and Tax Education with Level of Tax Compliance: A Study the Influences of Religiosity. ASEAN Journal of Economics, Management and Accounting, 1(1), 118-129.

Mohd Yahya Mohd Hussin, Fidlizan Muhammad \& Mohamad Ali Roshidi Ahmad. (2013). Kepatuhan Membayar Zakat: Analisis Kutipan dan Ketirisan Zakat Fitrah di Selangor. Jurnal Syariah, 21(2), 191-206.

Mujaini Tarimin. (1995). Zakat Pengajian: Satu Penilaian Terbaru di Malaysia. Thesis Ph.D Universiti Malaya

Nor Azlina Abd Wahab \& Abdul Rahim Abdul Rahman (2012). Efficeiency of Zakat Institutions in Malaysia: An Application of Data Envelopment Analysis. Journal of Economic Cooperation and Development ,33(1), 95-112.

Nor Ghani Md Nor, Mariani Majid, Jaafar Ahmad \& Nahid Ismail. (2001). Can Privatization Improve Performance ? Evidence from Zakat Collection Institutions. Kertas kerja dibentangkan di Bengkel Ekonomi Islam. Fakulti Ekonomi, Universiti Kebangsaan Malaysia.

Norlela Zaman \& Hairunnizam Wahid. (2014). Pewartaan Zakat Pendapatan dan Trend Kutipan Zakat Pendapatan: Kajian di Malaysia. Prosiding PERKEM ke-9, 199-207.

Nur Azura, S., Norazlina A.W. \& Nor Fadzlin, M.B. (2005). Gelagat Kepatuhan Pembayaran Zakat Pendapatan: Kajian Kes UUM. dalam Seminar Ekonomi dan Kewangan Islam. Fakulti Ekonomi, Universiti Utara Malaysia.

Nur Barizah Abu Bakar \& Hafiz Majdi Abdul Rashid, (2010). Motivations of Paying Zakat on Income: Evidence from Malaysia. International Journal of Economics and Finance, 2 (3), 76-84.

Palil, M. Rizal. (2010). Tax Knowledge and Tax Compliance Determinants in Self Assessment System in Malaysia. Thesis of Department of Accounting and Finance Birmingham Business School The University of Birmingham.

Pusat Pungutan Zakat Kuala Lumpur. (2014). Ringkasan Laporan Zakat PPZ-MAIWP 2013. Kuala Lumpur:PPZ-MAIWP.

Richardson, G. (2006). Determinants of Tax Evasion: A Cross Country Investigation. Journal of International Accounting, Auditing \& Taxation, $15,150-169$.

Rini Hastuti. (2014). Tax Awareness and Tax Education: A Perception of Potential Taxpayers. International Journal of Business, Economics And Law, 5(1),83-91.

Roberts, M.L. (1994). An Experimnetal Approach to Changing Taxpayers' Attitude Toward Fairness and Compliance via Television. The Journal of American Taxation Association, 16, 67-86.

Sadeq, AHM. (1995). Ethioco-eco-Institution of Zakah: An Instrument of Self-Reliance and Sustainable Grass-Root Development (Mimeograph).

Sanep Ahmad. (2004). Kepatuhan Bayaran Zakat kepada Institusi Formal Kutipan Zakat. Laporan Teknikal Penyelidikan EP-003-2004. Fakulti Ekonomi dan Perniagaan, Universiti Kebangsaan Malaysia

Sanep, A., \& Hairunnizam, W. (2005). Persepsi Agihan Zakat dan Kesannya Terhadap Pembayaran Zakat Melalui Institusi Formal. Jurnal Ekonomi Malaysia, 39, 5369.

Siti Saufirah Mohd Tahir, Hairunnizam Wahid \& Sanep Ahmad. (2015). Kepatuhan Membayar Zakat Fitrah: Analisis Kutipan dan Ketirisan Pembayaran Zakat Fitrah di Terengganu. eProsiding Seminar Fiqh Semasa (SeFis), 1-9. 